\title{
The Nutritional Habits of College Students: A Study of Wiawso College of Education
}

Nana Akua Osei-Tutu *

Tutor, Wiawso College of Education, P.O. Box 97, Sefwi- Wiawso, Western North Region- Ghana

\section{Article History}

Received: 24.08 .2020

Accepted: 10.09 .2020

Published: 14.10 .2020

Journal homepage:

https://www.easpublisher.com/easjnfs

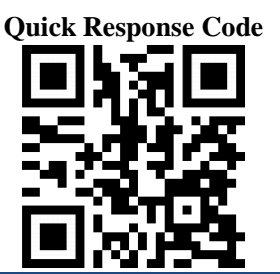

Copyright (C) 2020 The Author(s): This is an open-access article distributed under the terms of the Creative Commons Attribution 4.0 International License (CC BY-NC 4.0) which permits unrestricted use, distribution, and reproduction in any medium for non-commercial use provided the original author and source are credited.

\section{INTRODUCTION}

Nutrition is the study that focuses on food and substances in food that help humans grow and stay healthy. Nutrition is one key to developing and maintaining a state of health that is optimal for humans, in broader definition nutrition includes the social, economic, cultural and psychological implications of food and eating [1].

Food plays an important role in nutrition and can be considered an important ingredient in the academic and holistic development of students.

According to the study by Haberman and Huffery [2], students consumed a higher quantities of total fat, sodium, cholesterol and however inadequate amounts of fruits and vegetables and also had no exercise patterns.

The purpose of this study is to investigate the nutritional habits and patterns of college students in relationship to healthy eating. The study will study the food choices of students and their challenges in choosing healthier options.

The study will be carried out on the campus of Wiawso College of Education in the Western North Region of Ghana.

\section{LiTERATURE REVIEW}

Nutrition has been with life since creation. The ancient theory of nutrition considered nutrition as an important part of health, disease, performance and healing. The power in each part of the body is believed to be dependent on the blood flowing through the body which is made of nutrients absorbed from the diet $[3,4]$. Ancient doctors and philosophers were able to predict a general dietary map without having a clear understanding of how the human body works.

The modern theory of nutrition has taken a step ahead especially with the discovery of vitamins and minerals between 1910 and 1930. Nutrition is the science of foods and the nutrients and other substances they contain and of their actions within the body through injection, digestion, absorption, transport, metabolism and excretion. A broader definition includes the social, economic, cultural and psychological implications of food and eating [1]

College of education students in Ghana currently have to spend eight semesters in school before completing in four years. During this time, students spend in school; they face many new experiences on their own [5]. 
In college, students are not under the influence of their parents and have to make new decisions that influence their food and beverages, and nutrition as a whole [6]. According to Waterhouse et al. [14], a lot of factors influence the food and foodservice in colleges which include personal preferences, peer influence, time schedules, foodservice systems and financial resources. The effects of these factors could be positive or negative, consequently a number of studies have argued that dietary choices of students are low in quality in relation to nutrition. Researchers reported that college students have poor feeding habits that may present barriers to achieving optimal nutrition [7]. Deshpande, Brasil \& Brasil [8] also said students' food choices today can influence their development of conditions like osteoporosis, diabetes, stroke, cardiovascular diseases and forms of cancers.

In a research by Glanz et al. [2], it was found that taste, nutrition, cost ,convenience and weight management in influencing food choice is based on personal demographics and values.

Research has found that student's diet is typically low or deficient in levels of vitamins and minerals such as calcium, iron, Vitamin A, vitamin $\mathrm{C}$, and fibre $[9,10]$.

A substantial number of students are not only consuming diets low in fruits and vegetables but results from the study by Kim et al. [5], found that students have developed a liking for fast food which contain a higher amount of sodium, Fat and unhealthy food additives.

Doherty et al. [11], identified some barriers to students eating a healthier diet, which include: time, money and knowledge of constituents of a balanced diet, they need further motivation to implement the knowledge they may have acquired through various means.
Decrease in dietary quality and irregular meal patterns can lead to increased weight and further lead to obesity according to a study by Spanos \& Hankey.

The flavour, appearance and the taste are important things students use to judge and select food items [12].

\section{MeTHODS}

The researcher used a descriptive research design; interview was used to collect data. The target respondents were from Wiawso College of education comprising both male and female from either first or second year of their study. Simple random sampling was used to select 150 respondents through interview with the use of an interview guide to collect data. The interview guide consisted of two main sections, the first part was used to collect demographic data and the second section collected data pertaining to the nutritional behaviour of students. The research approach is qualitative. The data was analysed with Microsoft word and excel.

The consent of all those who participated in the interview was sought. They were assured of the confidentiality of information obtained and anonymity [13].

\section{FINDINGS}

The data of the study was collected by interview with an interview guide with 150 people randomly sampled comprising 47 males and 103 females. The age range was 20-29 with more than half of the respondents between the age of 21 and 23 years. The respondents were sampled from all programmes of study at Wiawso college of education; home economics, agricultural science, technical skills and general science.

Table one is the number of respondents broken down based on their response to the numbers of meals taken on a daily bases.

Table-1: Response to number of meals taken in a day.

\begin{tabular}{|l|l|l|}
\hline $\begin{array}{l}\mathbf{4} \text { meals comprising breakfast, lunch and } \\
\text { supper and a snack. }\end{array}$ & $\begin{array}{l}\text { 3 meals comprising breakfast, } \\
\text { lunch, supper. }\end{array}$ & $\begin{array}{l}\mathbf{2} \text { meals comprising brunch } \\
\text { and supper. }\end{array}$ \\
\hline 27 respondents & 110 respondents & $\mathbf{1 3}$ respondents \\
\hline
\end{tabular}

The respondents answer to their sources of daily meals is tabulated in table 2 below. It is evident that the major source of meals for the respondents was the dining hall. The dining hall operated on a cyclical menu with no room for variety; however, students on special diets were given consideration based on their physician advice.

Table-2: Sources of meals

\begin{tabular}{|l|l|l|l|}
\hline $\begin{array}{l}\text { 3- Dining hall, vendors, } \\
\text { friends and family }\end{array}$ & $\begin{array}{l}\text { 2- Dining hall } \\
\text { and vendors }\end{array}$ & $\begin{array}{l}\text { 2-Dining hall and } \\
\text { family and friends }\end{array}$ & 1- Dining hall \\
\hline 21 & 71 & 13 & 45 \\
\hline
\end{tabular}


The interview went further to inquire about the dislikes and reservations from the college students about the dining hall service. 67 respondents answered with $\mathrm{NO}$, and their reasons were: financial constraints, time constraints and value for money; since the dining hall meals is free. 83 respondents answered YES and their reasons were:

1. Suffering adverse health situations such as stomach ache, rashes after taken certain foods from the dinning hall

2. Non- preference for certain foods.

3. Limited variety of meals.

4. Hygienic practices associated with food preparation and service.

5. Poor quality of some foods

6. Special diet requirements for some college students.
30 respondents had no reservation about the institutional time schedule for taking dining hall meals; consequently, 95 respondents had reservation with reasons such as:

The time intervals between the meals were inappropriate, for example breakfast is taken at 9:30 $\mathrm{am}$, lunch at 2:00pm and supper at 5:00pm. They complained time between lunch and supper is too close compared to breakfast.

Occasionally, too much class activity, social activity and assignment may cause students to miss dining hall meals and have to find alternate sources of meals.

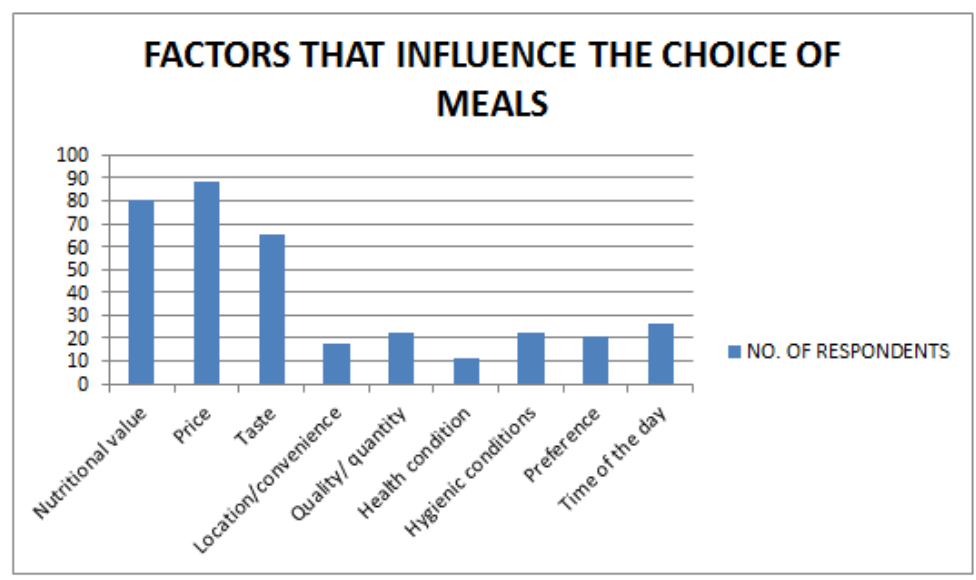

Fig-1: Factors that influence the choice of meals

From the data presented in the bar chart above, price was the most chosen factor for choosing meals, followed by the nutritional value and then taste. A conclusion can be drawn from the table that price, nutritional value and taste were factors they considered to be of most importance when choosing meals (please note that this was a multiple response question).

The data collected from the study agrees with the research by Glanz et al. [2], the researcher stated that taste, nutrition, cost ,convenience and weight management in influencing food choice is based on personal demographics and values.

In responding to students favourite meals, only $10 \%$, that is 15 respondents choose meals that can be considered as fast foods whilst $90 \%$ choose cooked that can qualify for healthy balanced diets. This information is represented in figure 2 below.

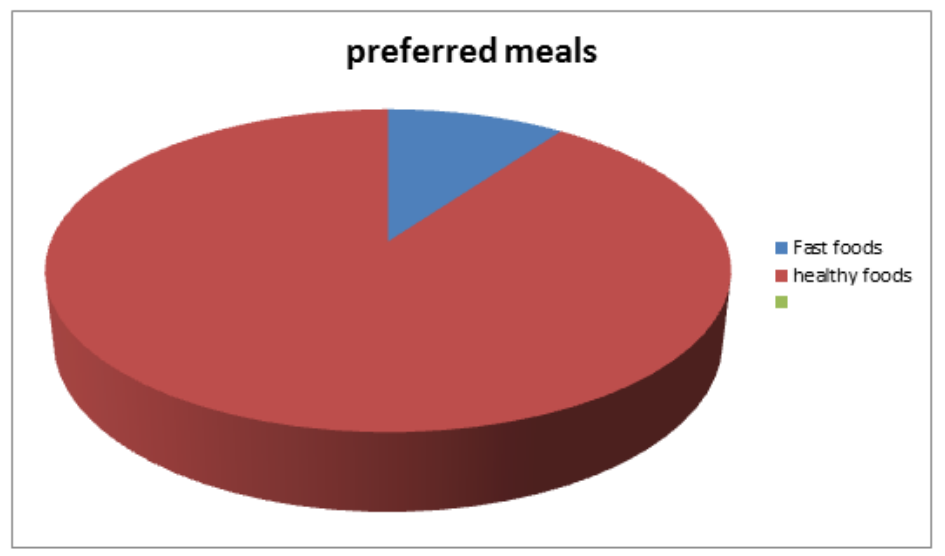

Fig-2: Analysis of students preferred meals 


\section{CONCLUSION}

The findings from the study were in line with Poddler et al 2012 and Grahana \& Laska 2011 that food choices are greatly influenced by the college experience. From the study students had three main sources to obtain food with majority of students eating from the dining hall because it is convenient and free. In totality, the numbers of choices students have to choose from were limited.

Data collected from the respondents on the factors that influence their choice of meals, taste, nutrition and price ranked higher than the other factors. This is in line with the study of Glanz et al. [2], which found taste, nutrition and price to be high ranking influences of food choices.

Data collected from the study suggested that the choices available to students were limited. The convenient choice was the dining hall which was free and available. Occasionally, students purchased food from vendors or received food from family and friends. Even though some students had knowledge of healthy eating and balanced diets they were restricted by variety, cost and time. In response to their preferred food choice, about $90 \%$ choose foods that can be considered healthy meals and the remaining 10\% choose fast foods. According to Kim et al. [5], students have developed a liking for fast food which contains a higher amount of sodium. Fat and unhealthy food additives, however, the findings from this study said otherwise.

\section{RECOMMENDATION}

The researcher from the study recommends that further research be carried out on nutritional habits of college students in relation to the measurement of body mass index (BMI). This study will help to further reveal and educate college students on healthy weight management which is to a large extent dependent on food choices and patterns.

\section{REFERENCES}

1. Whitney, E. \& Rolfes, S.R.(2008). Understanding Nutrition(11ed.) Wadsworth: Cengage learning.

2. Glanz, K., Basil, M., Maibach, E., Goldberg, J., \& Snyder, D. (1998). Why Americans eat what they do, taste, nutrition, cost, convenience, and weight control concerns as influences on food consumption. J Am diet assoc, 98 (10), 1118-1126.

3. Boylan, M. (2007). Galen on blood, the pulse and the arteries. Journal of the history of biology, 40(2), 207-230.

4. Guggenheim, K. (1981). Nutrition and nutritional diseases. The evolution of concepts. Lexington, Mases. D.C. Health \& Co.

5. Kim, H.S., Lee, S.M., Yuan, J.J. (2012). Assessing college students satisfaction with university food service. Foodserv. Bus. Res, 15(1), 39-48.

6. Graham, D.J., \& Laska, M.N. (2011). Nutrition label use partially mediates the relationship between attitude toward healthy eating and overall dietary quality among college students. J Am diet assoc.

7. Cousineau, D., Brown, S., \& Heathcote, A. (2004). Fitting distributions using maximum likelihood: Methods and packages. Behavior Research Methods, Instruments, \& Computers, 36(4), 742756.

8. Greaney, M.L., Less, F. D., White,AA., Dayton,S.F., Riebe D., Blissmer, B., \& Greene, G.W. (2009). College student's barriers and enablers for healthful weight management: a qualitative study. J Nut Educ Behav, 41(4), 281286.

9. Asiimwe, J.K. (2008). Dietary intake and nutritional status of university of Wisconsin. Stout students.

10. Merkle, E. (1998). The relationship between meal plans and nutritional intake of college students. (Masters of science Master's thesis), Ohio State University.

11. Doherty, T. J., \& Clayton, S. (2011). The psychological impacts of global climate change. American Psychologist, 66(4), 265.

12. Zabriske, M., \& Blacburn, R. (2006). Designing purposeful educational interventions and assessments in collegiate dining environments; the great plate program. Journal of food service management \& education, 2(1), 1-11.

13. Ary, D., Jacobs, L. C., Sorensen, C. \& Razavieh, A. (2009). Introduction to research in Education, $8^{\text {th }}$ edition. Wadworth publishing.

14. Waterhouse, Bailey, L., Tomlinson, F. Edwards, B., Atkinson, G., \& Reilly, T. (2005). Food intake in healthy young adults: effects of time pressure and social factors. Chronobiol Int, 22(6), 1061092). 